\section{Histological Studies on the Black Discoloration of Peach Fruit Skin Exposed to Iron}

\section{Osamu Arakawa \\ Faculty of Agriculture, Hirosaki University, Hirosaki, Aomori 036, Japan}

Joe M. Ogawa

Department of Plant Pathology, University of California, Davis, CA 95616

Additional index words. anthocyann, ferrous sulfate, tannin, Prunus persica

Abstract. The skin of 'Elegant Lady' peach [Prunus persica (L.) Batsch.] fruit turned black when exposed to $100 \mathrm{ppm}$ ferrous sulfate solution. This color change appeared on the red and the yellow portions of the fruit. Microscopy of the skin showed blue-black pigment distribution in epidermal and hypodermal tissues. Some epidermal and hypodermal cells discolored immediately when exposed to ferrous solutions, but many cells turned black later. Some cells with anthocyanin pigments did not discolor. Chromic acid showed that tannic substances were distributed in the epidermal and hypodermal cells, and they likely are the main factor in black discoloration of peach fruit exposed to solutions containing Fe.

Peach skin discoloration or inking is a disorder confined to the surface of peach or nectarine fruit. This disorder is enhanced by vibration, excessive brushing, and a high $\mathrm{Fe}$ content in the hydrocooling water (Hopfinger, 1990). The anthocyanin pigment cyanidin-3glucoside has been implicated, and its color is readily modified by the $\mathrm{pH}$ of the hydrocooling water, chemical reactions, or both (Denny et al., 1986). The initial symptoms are watersoaked areas on the red surface that eventually turn purplish-black (Hopfinger, 1990). Hopfinger and Frecon (1986) attributed the discoloration in peaches to the presence of $\mathrm{Fe}^{2+}$ in the hydrocooling water and showed that increasing the water's $\mathrm{pH}$ to 6.5 decreased the $\mathrm{Fe}^{2+}$ level and thereby alleviated the problem. Iron apparently combines with an anthocyanin pigment in the peach skin, but there is no direct evidence that an $\mathrm{Fe}$-anthocyanin complex causes the discoloration. Peach skin contains catechin and chlorogenic acid, both of which turn black in the presence of $\mathrm{Fe}$ (Kubota et al., 1989; Reeve, 1959).

In this report, we present evidence that localization of the color change in peach fruit skin cells exposed to $\mathrm{Fe}^{2+}$ involves tannic substances.

\section{Materials and Methods}

'Elegant Lady' peach was harvested at the firm mature stage in a commercial orchard at Fresno, Calif. Fruit were not hydrocooled before analysis. Fresh sections were prepared by hand and dipped in $100 \mathrm{ppm}$ ferrous sulfate or

Received for publication 14 Apr. 1993. Accepted for publication 18 Aug. 1993. This work was supported by the California Tree Fruit Agreement. The cost of publishing this paper was defrayed in part by the payment of page charges. Under postal regulations, this paper therefore must be hereby marked advertisement solely to indicate this fact.
$1 \%$ chromic acid and observed under light microscopy.

\section{Results and Discussion}

The skin of 'Elegant Lady' peach fruit is made up of small epidermal cells, generally two to three cells deep, and a hypodermis of somewhat larger cells, three to four cells deep. Red-pigmented cells containing anthocyanin in their vacuoles are distributed throughout the epidermal and hypodermal cells (Fig. 1). In the highly colored area of the skin, anthocyanin is found in the deeper hypodermal cells.

'Elegant Lady' peach fruit treated with 100 ppm ferrous sulfate solution developed black spots or stripes within $3 \mathrm{~min}$ and subsequently turned completely black (Fig. 2). The degree of black coloration depended not only on the While black coloration was observed in the yellow area with no anthocyanin, the red areas turned much darker than the yellow areas. Vacuoles of ferrous-treated epidermal and hypodermal cells were blue-black (Fig. 3). Some red cells with anthocyanin appeared to be unaffected. In tissue treated with ferrous $\mathrm{Fe}$, some vacuoles in the epidermal and hypodermal cells immediately became discolored (Fig. 4a), but after several hours, many of these cells had blue-black vacuoles (Fig. 4b). Blueblack coloration occurred at random, and no difference in distribution of blue-black vacuoles between epidermis and hypodermis was evident. Some red cells were unaffected by Fe. The black pigment was stable for several days.

Our observations suggest that anthocyanin is not the only substrate for the black discoloration in the presence of ferrous solution. Ferrous sulfate and ferric chloride are used for fruit type, but also on the area of the fruit.

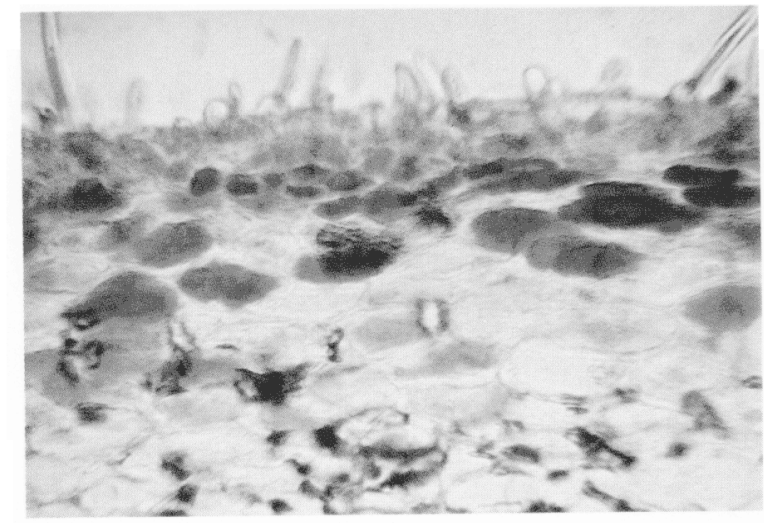

Fig. 1. Distribution of pigmented cells in hand-sectioned skin of 'Elegant Lady' peach $(\times 180)$.

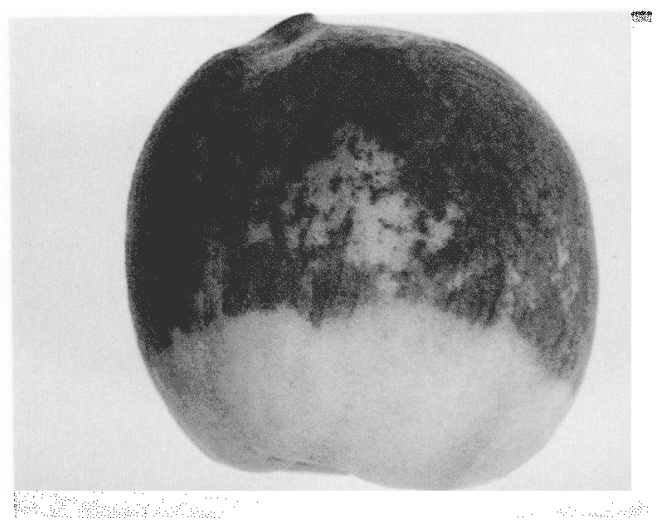

Fig. 2. Black coloration of 'Elegant Lady' peach fruit after exposure to ferrous 


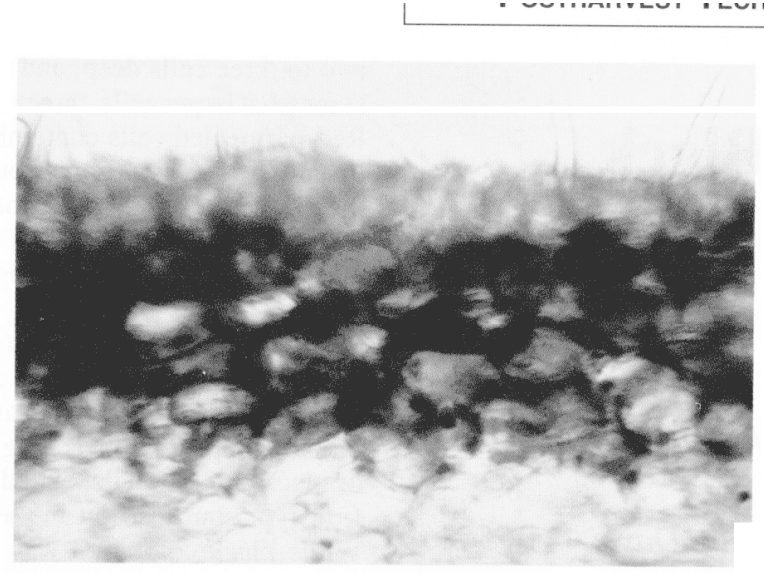

Fig. 3. Distribution of black cells in hand-sectioned skin of 'Elegant Lady' peach exposed to ferrous sulfate solution $(100 \mathrm{ppm})(\times 180)$.

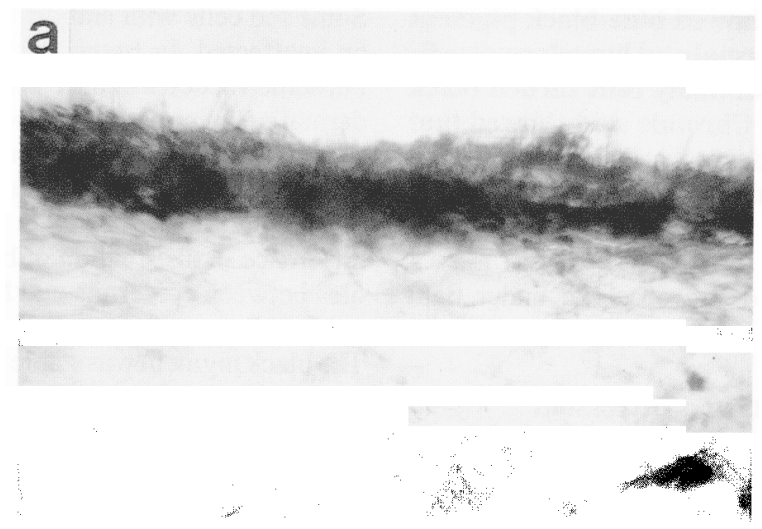

b
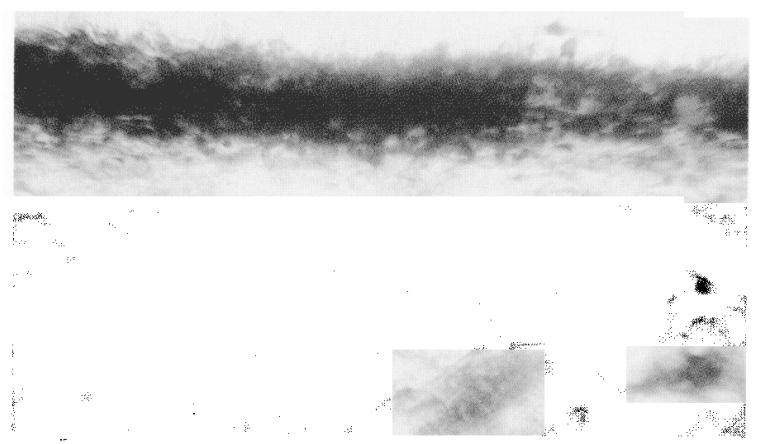

Fig. 4. Influence of time on skin discoloration of 'Elegant Lady' peach exposed to ferrous sulfate solution $(100 \mathrm{ppm})(\mathbf{a})$ immediately after preparation and $(\mathbf{b})$ after several hours $(\times 75)$.

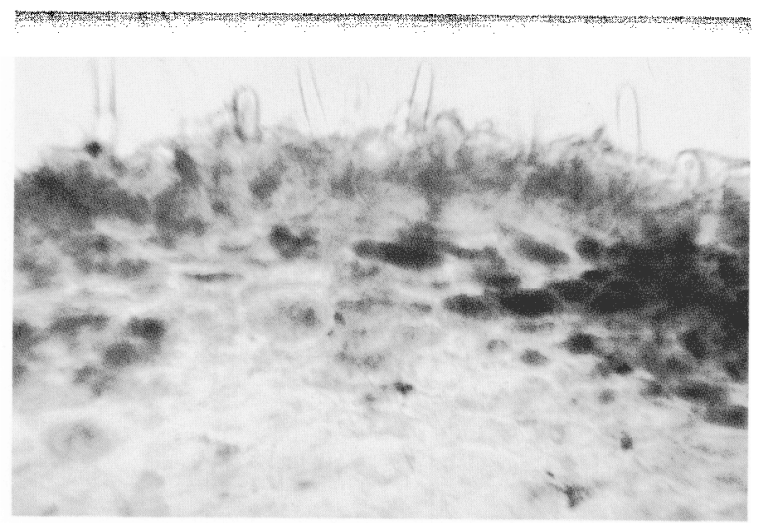

Fig. 5. Confirmation of catechin, as indicated by browning of peach skin exposed to $1 \%$ chromic acid $(\times 180)$. detecting tannic substances in plant tissue (Reeve, 1959). Catechin and chlorogenic acid are present in the peach fruit (Kubota et al., 1989; Reeve, 1959), and catechin in epidermal and hypodermal cells was confirmed with chromic acid as indicated by the brown in Fig. 5 (Yasuda, 1970). Therefore, blue-black coloration in the epidermal and hypodermal cells following exposure to $\mathrm{Fe}^{2+}$ could involve tannins. That yellow portions of fruit also turned black is further evidence that anthocyanin is not the sole substrate for the color reaction. Because cyanidin-3-glucoside-iron complexes depend on $\mathrm{pH}>5.5$ (Jurd and Asen, 1966), and $\mathrm{pH}$ values in peach and nectarine tissues are $<5.5$, it is unlikely that such complexes were formed in our study.

Although the symptoms of inking were similar to those reported by Hopfinger (1990) and Denny et al. (1986), tannic substances more likely are the main factor for black coloration in peach exposed to Fe. We, therefore, question the role of $\mathrm{Fe}$ in this disorder in the Fresno area because a) the water for hydrocooling was essentially free of $\mathrm{Fe}$ and $\mathrm{b}$ ) inking occurs in orchards with no history of spray applications of Fe. Brown discoloration may be related to injury that causes polyphenolic browning, especially with tannins (Chastagner and Ogawa, 1976; Wang and Mellenthin, 1973).

\section{Literature Cited}

Chastagner, G.A. and J.M. Ogawa. 1976. Injury of stone fruits by preharvest captan sprays followed by postharvest treatments. Phytopathology 66:924-927.

Denny, E. G., D.C. Coston, and R.E. Ballard. 1986. Peach skin discoloration. J. Amer. Soc. Hort. Sci. 111:549-553.

Hopfinger, J.A. 1990. The role of postharvest handling and peach skin discoloration. Acta Hort. 254:167-173.

Hopfinger, J.A. and J.L. Frecon. 1986. The role of iron $\left(\mathrm{Fe}^{+2}\right)$ in peach skin discoloration. HortScience 21:754.

Jurd, L. and S. Asen. 1966. The formation of metal and "copigment" complexes of cyanidin 3-glucoside. Photochemistry 5: 1263-1271.

Kubota, N., H. Yakushiji, A. Kobayashi, and K. Shimamura. 1989. Phenolic compositions in peach fruits. J. Jpn. Soc. Hort. Sci. 58(Suppl. 1):96-97.

Reeve, R.M. 1959. Histological and histochemical changes in developing and ripening peaches. III. Catechol tannin content per cell. Amer. J. Bet. 46:645-450.

Wang, C.Y. and W.M. Mellenthin. 1973. Relationship of friction discoloration to phenolic compounds in 'd'Anjou' pears. HortScience 84:321322.

Yasuda, H. 1970. Studies on "bluing effect" on the petals of red rose, I. Some cytochemical observations on epidermal cells having a bluish tinge. Bet. Msg. Tokyo 83:233-236. 